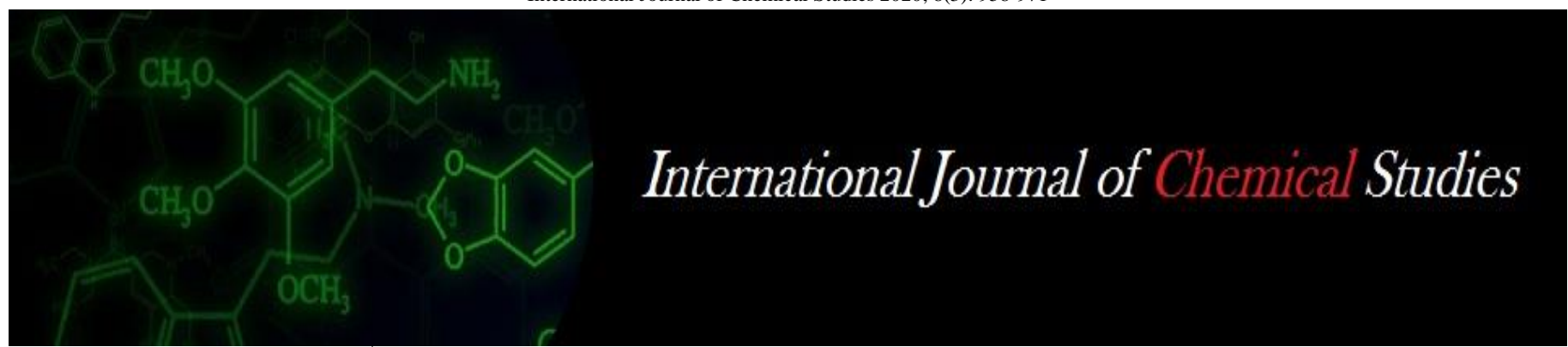

P-ISSN: 2349-8528

E-ISSN: 2321-4902

www.chemijournal.com

IJCS 2020; 8(3): 958-971

(C) 2020 IJCS

Received: 21-03-2020

Accepted: 22-04-2020

Siddhartha Das

Department of Plant Pathology,

M.S. Swaminathan School of

Agriculture, Centurion

University of Technology and

Management, Paralakhemundi,

Odisha, India

Sudeepta Pattanayak

Department of Plant Pathology,

M.S. Swaminathan School of

Agriculture, Centurion

University of Technology and

Management, Paralakhemundi,

Odisha, India

\section{Madhavi Bammidi}

Department of Plant Pathology, M.S. Swaminathan School of Agriculture, Centurion

University of Technology and Management, Paralakhemundi, Odisha, India

Corresponding Author: Siddhartha Das

Department of Plant Pathology, M.S. Swaminathan School of Agriculture, Centurion University of Technology and Management, Paralakhemundi, Odisha, India

\section{A real time surveillance on disease and pest monitoring, characterization and conventional management strategy of major cultivated crops in tropical savanna climatic region of Srikakulam, Andhra Pradesh}

\author{
Siddhartha Das, Sudeepta Pattanayak and Madhavi Bammidi
}

DOI: https://doi.org/10.22271/chemi.2020.v8.i31.9324

\begin{abstract}
Plant disease is defined as a malfunction or dysfunction of plant physiological normal activities with addition of behaviousristic or morphological changes of normal cell shape and size. Surveillance is an active or passive way of collecting, analyzing, interpreting information on disease occurrence in specified area which is further utilizable to control the effectiveness of the specified disease. Rural Entrepreneurship Awareness Development Yojana (READY) is a real time based experiential learning programme with combination of field based practical training and business application in agriculture sciences. Centurion University of Technology and Management (CUTM) every year organized READY programme under the curriculum of agriculture which helps in one direction to for in hand training of new agriculturist, on the other hand it transferred new modern scientific skills to the poor grass hood level farmers. This programme revealed with some remarkable data's of some severe pest-disease infestation in a broader spectrum. Different biotic factors will considered to be the most influential factor among them. Major diseases and pests include rice blast, northern corn blight, black rot of cole crops, chilli leaf curl virus etc. The different types of pests observed are sucking pests, fruit borers, leaf rollers, leaf eating caterpillars etc. and their incidence level ranged between $25-60 \%$. Crucial epidemiological factors like moderate temperature $\left(30-35^{\circ} \mathrm{C}\right)$, high humidity $(85-90 \%)$ and scattered rainfall $(120-150$ $\mathrm{mm}$ ). The present investigation through real time surveillance and monitoring, we are trying to focus major biotic stresses, their behaviouristic nature and their conventional management strategy which applied for long time.
\end{abstract}

Keywords: Surveillance, pathogenic diseases, pests, biotic, epidemiological factors

\section{Introduction}

READY program is a yojana of ICAR launched in 2015 by Prime Minister Narendra Modi for the skilled based knowledge transfer and practical based in hand experience learning programme in agriculture sciences. READY programme combines with 3 projects i.e., AELP (Agricultural Experiential Learning Progrmme), RAWEP (Rural Agricultural Work Experience Programme), AIA (Agro-industrial Attachment).

Objectives of READY programme are:

i) To acquaint new era agriculturalist into rural areas, farm conditions and problems faced by the farmers

ii) To apply the theoretical knowledge, practically in the fields and improve modern technical skill.

iii) To realize the real-life situations of the villagers and their agro-economic situation.

iv) To know the impossibilities of lab techniques in fragmented land conditions and field based experimental trial.

v) To study pest and pathogen activity and their nature of severity in various climatic conditions.

The area selected for RAWEP is Srikakulam district is in the geographical position of $18^{\circ}-20^{\prime}$ and $19^{\circ}-10^{\prime} \mathrm{N} 83^{\circ}-50^{\prime}$ and $84^{\circ}-50^{\prime} \mathrm{E}$, Pathapatnam mandal, Korasavada village, Sivarampuram 
village, Borubadhra village (Figure 1). District is bordered by coastal area i.e., Bay of Bengal on east side and in south by Vizianagaram district and in north and west by Odisha state. District is bordered by $193 \mathrm{~km}$ of coastal length. RAWEP conducted in the area is starting with survey on village historical development, village economic status, previous and current agricultural status, availability of resources, availability of inputs, availability of agricultural services etc., skills will transferred in terms of land preparation, nursery sowing, transplantation, irrigation, pest and disease management activities, harvesting, marketing, storaging. The area selected should be a rural area which provides students to a direct contact with farmers of that area to know the real-life conditions and situations of them. Mostly the farmers in the villages are small to medium land holders i.e., small to marginal land holders between 2-10ha of land and heterogenic fields with various cropping systems. They depend on their agricultural income; some small land holders depend on labor wages in other fields too. Some farmers having oxen, they used it for land preparation and given to other farmers for money like rental for land preparation. Most of the farmers having no machinery like tractor, combined harvester etc., farmers who are having machinery giving on rental basis to others and get additional income. The lands observed are rainfed and borewell irrigation to some fields previously, but after 2014 lift irrigation scheme started in villages, most rainfed lands become irrigated, in large area villages like Korasavada 2 lift irrigation projects are there. For initial crop investments, most of the farmers lend money from cooperative society and some from private lenders. Substitute to agri-income farmers also engaged in other activities like dairy maintenance, the waste products like dung and urine are used for composting and used to applying the fields during land preparation and the main products like milk are used for own consumption and for selling purpose in the village itself to neighbors. By this they are creating additional income. Mostly these villages having upland than low land which is sandy loamy and most suitable foe vegetable growing by which they are gaining more income from those lands when compare to sowing agronomic crops in those lands.

As the villages selected are mostly suitable for vegetable growing, they are mostly proned to disease and pest attack. Under this RAWEP scheme different awareness programmes are also conducted in village for farmers about severe diseases and pests that how they attack, what are the symptoms, how to manage at base level, practices to be followed at ETL stages, chemical management methods and during application of pesticides, precautions to be followed by the farmers and the color indicating rhombus symbols on pesticide bottles, sachets etc., what the color indicates, when it to be used, what the level of toxicity indicating the color etc. The different types of diseases observed in the village are infectious or pathogenic diseases, physiological diseases, deficiency diseases etc. Farmers are following the chemical management practices along with some traditional techniques. The significance of disease surveillance is to observe, analyze, predict and minimizing the predicted disease loss which may be either due to seed borne or soil borne. The pest and diseases are attack is generally observed at the vegetative stages as well as reproductive stages which gradually lead to yield losses upto 25 to $60 \%$. In recent perspective real time nematode survey and surveillance work was done by Fatma and Singh (2019) ${ }^{[9]}$. Surveillance based research work is now not only restricted in cultivated crops but also insect-pests infestation of medicinal crops were reported by Sharma et al., (2014) ${ }^{[15]}$. The surveillance data should be simple, acceptable, flexible and effectively useful for cost of a managing system.

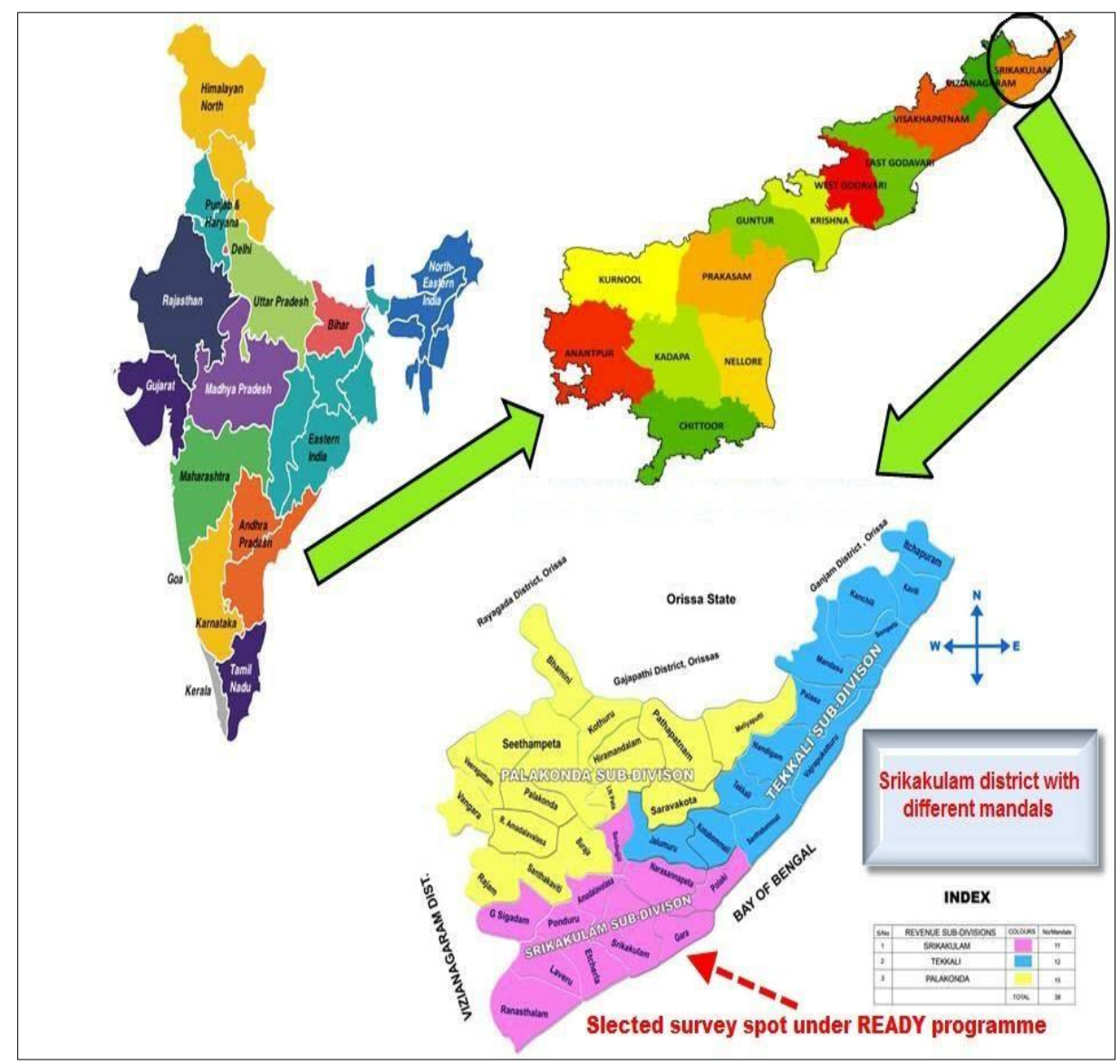

Fig 1: Agro-geographical location of selected survey spot under READY programme $\sim 959 \sim$ 


\section{Material and Methods}

\section{Survey region selection}

The selected region for survey is rural areas and that too an agriculture-based areas, in which the villages Korasavada, Borubadhra, Sivarampuram most of the women are engaged in self-help groups. The average landholding capacity of famers is 1.80 acres and farmers mostly cultivate rice, maize, sugarcane, blackgram, sesame and vegetables like cauliflower, chilli, brinjal, raddish, taro etc. Villagers follow both traditional as well as chemical methods. Initially the farmers are not interested to follow the organic ways cultivation methods, slowly after knowing the benefits and decreasing cost of cultivation they are start following organic methods. The aforesaid regions were choosing based on their low agro-economic situation and by repeated year from that region disease and pest infestation rate is more than compared to other regions.

\section{Different parameters of the data collection}

Parameters used in data collection are conventional method they are randomization, blocking, replications which gives précised results and may have some limitations like small plots. The data collections were done directly by new agriculturists, to avoid complications in questions. For farmers if any unknown person directly asks the questions about their occupation they could not answer clearly. The way of interviewing a farmer should be indirect method by which they can answer easily.

3. Questionnaires to all agro-economic classes of farmers As a part of the project, recruited agriculturists must suggest some information to farmers; SHG groups other villagers and gather some traditional knowledge from them. For that it, must be know the details of the farmers previously and their technical skills in management practices and agro-economic status. For this we conduct the triangulation method of survey in which we collect data from groups having 3 members. It is to cross check the collected information and it also increases the efficiency of data. The selected and served formats of questionnaires are presented under the Figure 2 and Figure 3.

1. Survey on

a. Adoption of recommendation on management practices for insect pests of crops by host farmer:

b. Incidence/ occurrence of different insect pests:

c. Precaution being taken by farmers while incorporating management practices:

d. Any cases of poisoning (humans/ animals) being reported in the area while incorporating chemicals:

2. Constraints/problems faced by the farmers regarding plant protection operations/ application of pesticides/ availability of pesticides and plant protection equipment etc.:

3. Critical observations on the plant protection measures adopted by the farmer (reasons for not adopting certain recommended practice/new practices adopted):

4. Normal and actual yield obtained by the plant protection measures and suggestions for improving the productivity of the crops by adopting the plant protection measures.

5. a. Awareness about Economic Threshold Levels of the pests:

b. Whether any farmer is following: 
Information on IDM to be collected in the form of Questionnaire from the host farmer

Name of Students:

Name of the Farmer:

Name of Crop/variety:

Date of Sowing:

1. What is IDM?

2. Do you know the components of IDM?

3. Which fungicides/bactericide is purchased by farmer?

4. Who suggested them to use in the crop?

5 . Source of purchase of fungicides/bactericide?

6. How you decide the quantity of fungicides/bactericide to be purchased?

7. How you prepare the solution?

8. Dou you use measuring cylinder, weighing balance for correct measurement of pesticide?

9. How you spray the fungicides/bactericides?

10. Whether the pesticide is applied alone or in combination?

11. Whether you know the dose of fungicides/bactericide, do you calculate the dose of fungicides/bactericide?

12. Time and dose of application of fungicides/bactericide?

13. Whether pesticides are applied as preventive or curative measures?

14. Do you know the precautionary measures to avoid poisoning?

15. Do you follow other methods of disease control?

16. Are the RAEO, extension workers/KVK's are guiding you in disease management?

Fig 2: Questionnaires format used on IPM practices followed by farmer

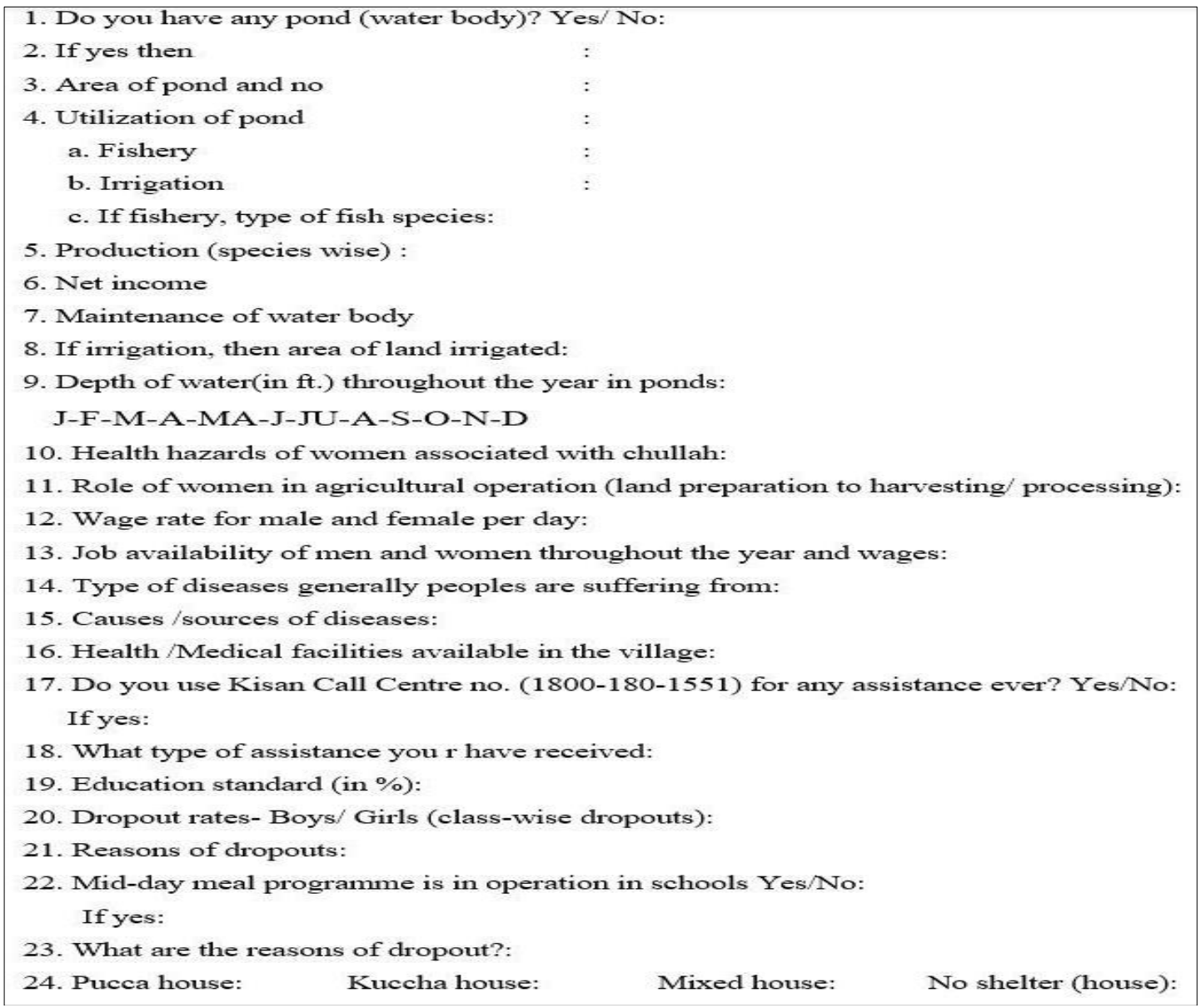

Fig 3: Questionnaires format used for agro-economic data collection 
25. Literacy rate:

26. Sources of income:

27. Land holding (in Acre):

28. Types of land (in Acre):
a. High
b. Medium
c. Low

29. Land utilization pattern- Topography wise

30. Economic status of the people (in \%) :
a. Rich
b. Medium
c. Poor

31. Do you add value of any agricultural produce? Yes /No:

If yes:

32. Mention the procedure and economics:

33. Is there any SHG (Self-Help Group)? Yes/No:
Medium
34. Name(s) of the group(s):
Medium
35 . Whether it is run by- only women / only men / both:

36. Number of members of the group(s):

37. Do you have the membership? Yes/No:

38. If yes, mention the detail activities of the group:

39. How SHG helps to empower women (mention in details):

40. How much do you get from SHG (in Rs.):

41. What do you do with your additional earnings from SHG (mention item wise):

42. If you do not have membership (explain reasons):

43. Where is the location of market (name and distance in $\mathrm{km}$.):

44. Do you always get the remunerative price? Yes /No:

45. If no, name the crop you did not get the remunerative price:

46. Please mention your marketing strategy (in details):

47. Do you know about any traditional storage system? Yes /No:

If yes, mention the structure and mechanism (in details):

48. Did you observed any changes in agricultural practices? Yes / No:

If yes what are the changes you observed (in details):

49. Do you feel climate change has any impact on agriculture? Yes /No:

If yes, mention the perception of changes you observed (in details):

50. What are the mitigation options you adapted?

\section{Disease incidence and pest incidence calculation}

Under consecutive survey most severe or destructive diseases were comes out. To measure the frequency of those diseases we are going through disease incidence calculation. If the survey plot is large in size, then the data's were taken from randomly selected small square blocks $\left(5 \times 5\right.$ meter $\left.^{2}\right)$. Formula of disease incidence is presented below.

Disease incidence $\%=$ No. of affected leaves /plant $/$ tiller Total no. of leaves / plant / tiller 100

For pest incidence calculation, we select a plot having symptoms of any crops. If the plot size is too large, randomly selected square plots in $5 \times 5$ or $1 \times 1 \mathrm{~m}^{2}$. Then it is calculated by formula:

Pest incidence $\%=$ No. of infested leaves /plant/ tiller Total no. of leaves / plant / tiller 100
5. Symptomatological study of disease and pest incidence

Symptomatological study of disease and pest incidence was done by comparative analysis of phenotypical characteristics with healthy plants and literature study. This step is very much important because without accurate disease and pest diagnosis, management will not be possible; simultaneously merging of various symptoms or it comes from micro nutrient deficiency that will failed to understand.

\section{Disease and management through conventional method}

Excessive use of agrochemicals must be restricted for our better future and to promote sustainable agriculture. Plianbangchang et al., (2009) ${ }^{[13]}$ were analyzed pesticide use 
pattern among small scale farmers in Thailand. Results revealed that till now there is a massive deficiency of skilled farmers. Complete eradication of micro-organisms and insects leads to resurgence of pest. So, using of conventional methods of pesticides kills only harmful pests. This type of strategies farmers has been used for long time. Under this method, different types of botanical biopesticides, conventional mixture and pastes and several other solution was used traditionally. Some of this conventional mixtures used as seed and seedling treatment, farm manure applications or used against diverse destructive disease pests and acts under the umbrella of sustainable agriculture. They are also used for better plant and seed vigor. Among which some of the conventional mixtures are discuss below.

The conventional or organic pesticides we also suggest through demonstrations in the villages are: (A) Beejamrutham (B) Neemastra (C) Agniastra (D) Panchagavya

\section{A. Beejamrutham}

The name indicates it is a seed treatment material, in which 'Beeja' means 'Seed'. Preparatory methodology is as per reported by Ingole et al., $2017^{[10]}$.

\section{Preparation method}

- Take a thin cloth or gunny bag and place $5 \mathrm{~kg}$ cow dung at the center which is easy to knot it. And place it in $20 \mathrm{~L}$ in water drum for $12 \mathrm{hrs}$.

- Add 50 gms of lime into 1L of water

- After $12 \mathrm{hrs}$ squeeze the cloth with cow dung and separate it.

- Then add 5L of desi cow urine into and also the lime solution into it and stir well

- It will be ready to use within $48 \mathrm{hrs}$.

\section{Application method}

- Seed dressing, root dipping of seedling.

- In some cases it also used as foliar application

- Used for seed borne diseases.

Note: lime solution is to reduce acidity and desi cow urine having more beneficial microorganisms than normal cow urine.

\section{B. Neemastra}

It is a broad-spectrum botanical pesticide which is used for wide range of insect pests This types of botanical pesticides are non-hazardous and non toxic for both crop and environment. It's also not harmful for other beneficiary insects and organisms. Sometimes botanical biopesticides are also used against different types of diseases.

The name indicates it contains Neem as main ingredient whose active ingredient is 'Azadirachtin'. Preparation technique is similar as described by Bishnoi and Bhati (2017) [1].

\section{Preparation method}

- $\quad$ Take $5 \mathrm{~kg}$ of neem leaves and crush them properly.

- Later add $5 \mathrm{~L}$ of design cow urine and $2 \mathrm{~kg}$ of cow dung.

- Ferment it for $24 \mathrm{hrs}$ and stir it in regular intervals.

- Further dilute it for $100 \mathrm{~L}$ water and use it as foliar spray.

Used for controlling of sucking pests, mealy bugs etc.

\section{Agniastra}

The name itself indicates 'Agni' which means 'Fire'. Means by using it insect body feels fire like sensation which leads to death of the insect. The effectivity of agniastra was also recommended by Khadse et al., (2017) ${ }^{[11]}$.

\section{Preparation method}

- Take the ingredients of Tobacco-50gm, Green chillies$50 \mathrm{gm}$, Garlic-50gm, Neem leaves-500gm and paste all those ingredients thoroughly into fine paste.

- Add this paste into $1500 \mathrm{~mL}$ of cow urine and boil it for 4-5 times.

- Leave it for $48 \mathrm{hrs}$ and filter it and store it.

- Before application dilute it for 5L of filtrate into $200 \mathrm{~L}$ of water and used as foliar spray.

Used for pests like leaf roller, stem borer, fruit borer, pod borer, cutworms etc.

Note: Fire sensation is due to nicotine in tobacco, diallyl disulphide in garlic, nicotine in neem, capsacin in chilli.

\section{Panchagavya}

The name "Panchagavya" indicates 5 products of cow i.e., cow milk, cow curd, cow ghee, cow urine, cow dung. The key role is to boosting immunity to the crop and acts as a plant growth promoter. Foliar application of "Panchagavya" was tested on leafy vegetable Sailaza et al., (2014) ${ }^{[14]}$. and preparatory methodology is quite similar with as per reported.

\section{Preparation method}

- $\quad$ First $7 \mathrm{~kg}$ cow dung and $1 \mathrm{~kg}$ cow ghee add well and keep it for 3 days.

- Later add 10L cow urine and 10L of water into it and keep it a side for 15 days by regular mixing.

- Add 3L cow milk and 3L cow curd into it and stir well and transfer it to earthen pot.

- Ferment it for another 15 days by regular stirring.

- Before application dilute 3L of Panchagavya in 100L of water.

- It shall be used as foliar spray, fertigation, seed treatment, root dipping.

Note: cow curd and cow urine after fermentation gives best results on insect pests and nutrients in the milk, ghee, curd acts as growth regulators.

In Maize a recent severe pest i.e., Fall armyworm Spodoptera frugiperda.

For this we suggest to use one conventional method along with poison bait. Conventional method is for initial stages of crop growth affected by initial stages of larvae i.e., filling of soil into center portion of plant.

The poison bait is prepared by using $2 \mathrm{~kg}$ jaggery, $2-3 \mathrm{~L}$ water, $10 \mathrm{~kg}$ rice husk and ferments it for $24 \mathrm{hrs}$ and thiodicarb of $100 \mathrm{gms}$ into and fill it into the center of maize plant this is for later stages of larvae.

\section{Results}

\section{Symptomatological expression of different crop} diseases

Prolonged survey and surveillance under repeated year helps to generate disease index, which is helpful for all agroeconomic classes of farmers. Beneficial aspect of such type of disease indexing is that farmers getting alert at right time with detail information of severe pest-pathogen attack and its management practices. Disease indexing and pest indexing is represented through Table 1 and Table 2. 
Table 1: Disease indexing, management practices and disease incidence level under different seasonal condition

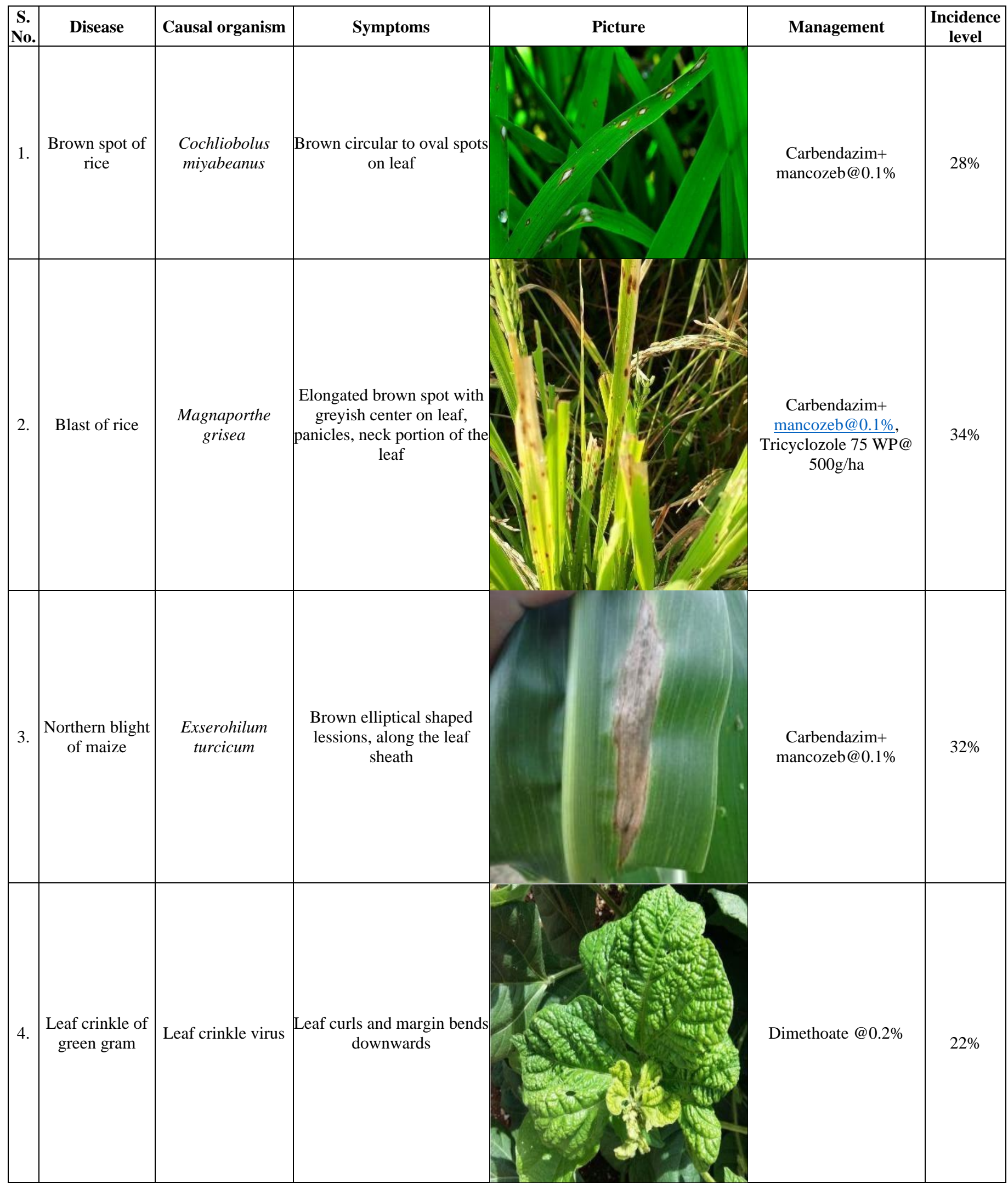




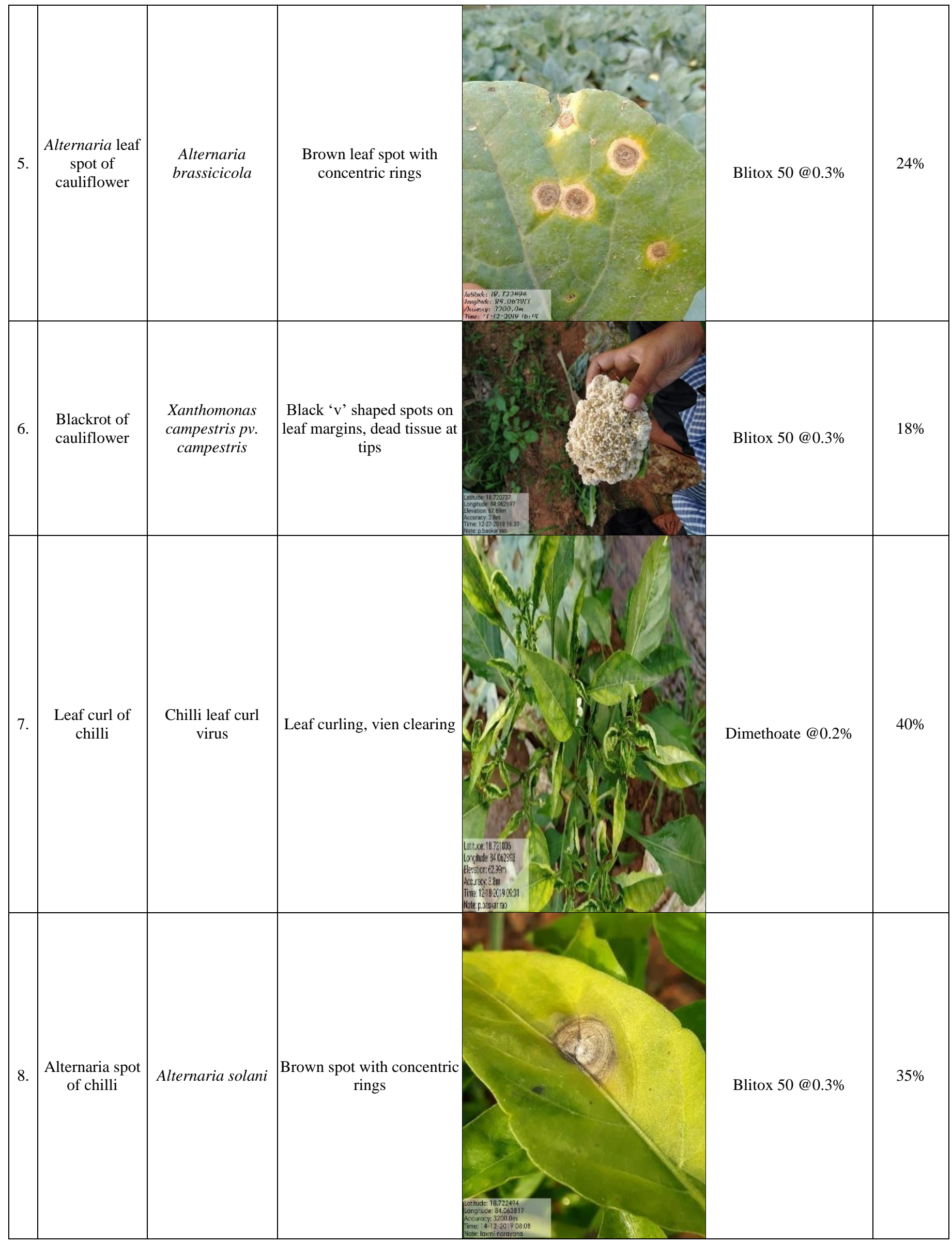




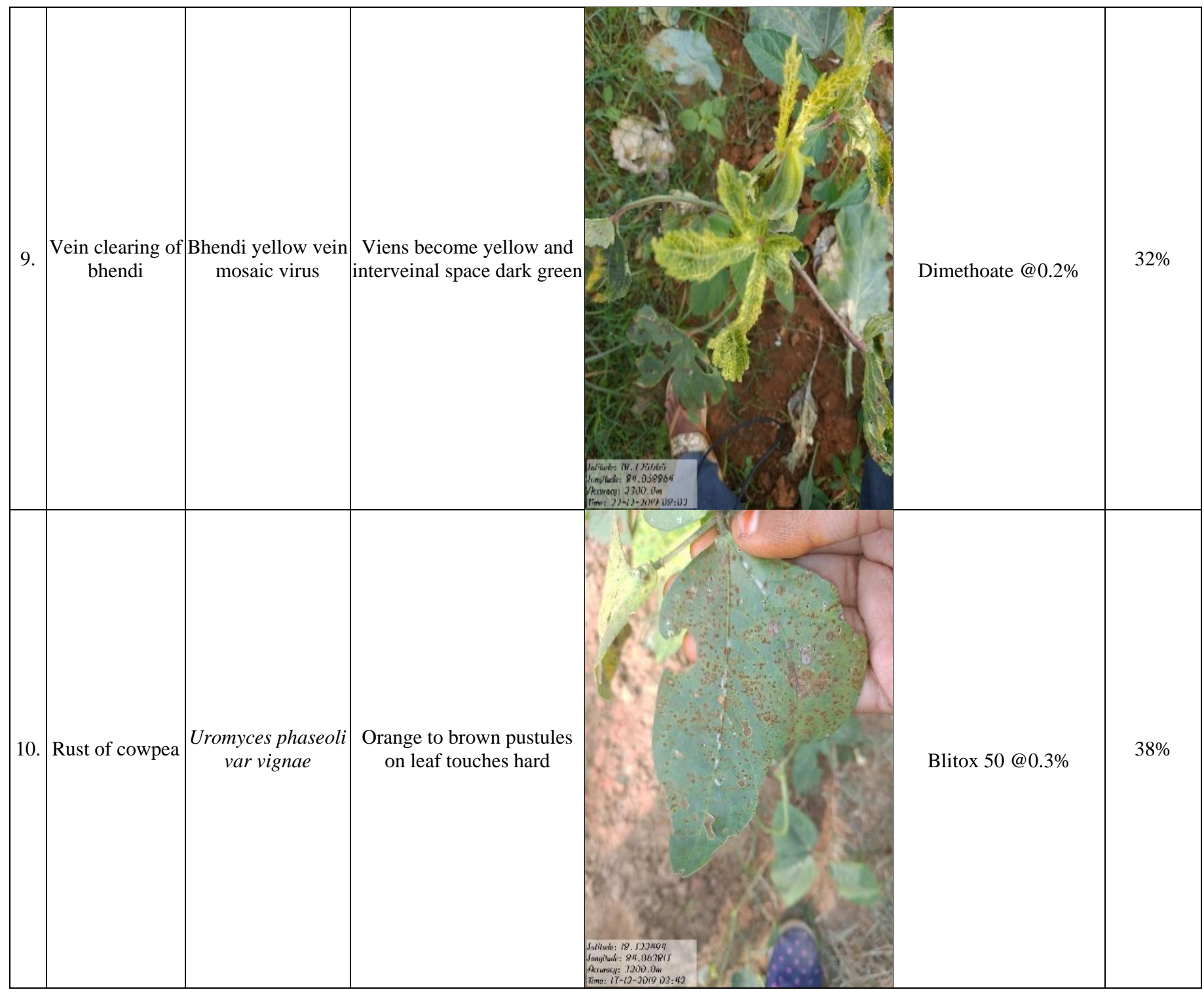

Table 2: Major pest infestation, symptomatic characterization, management strategy

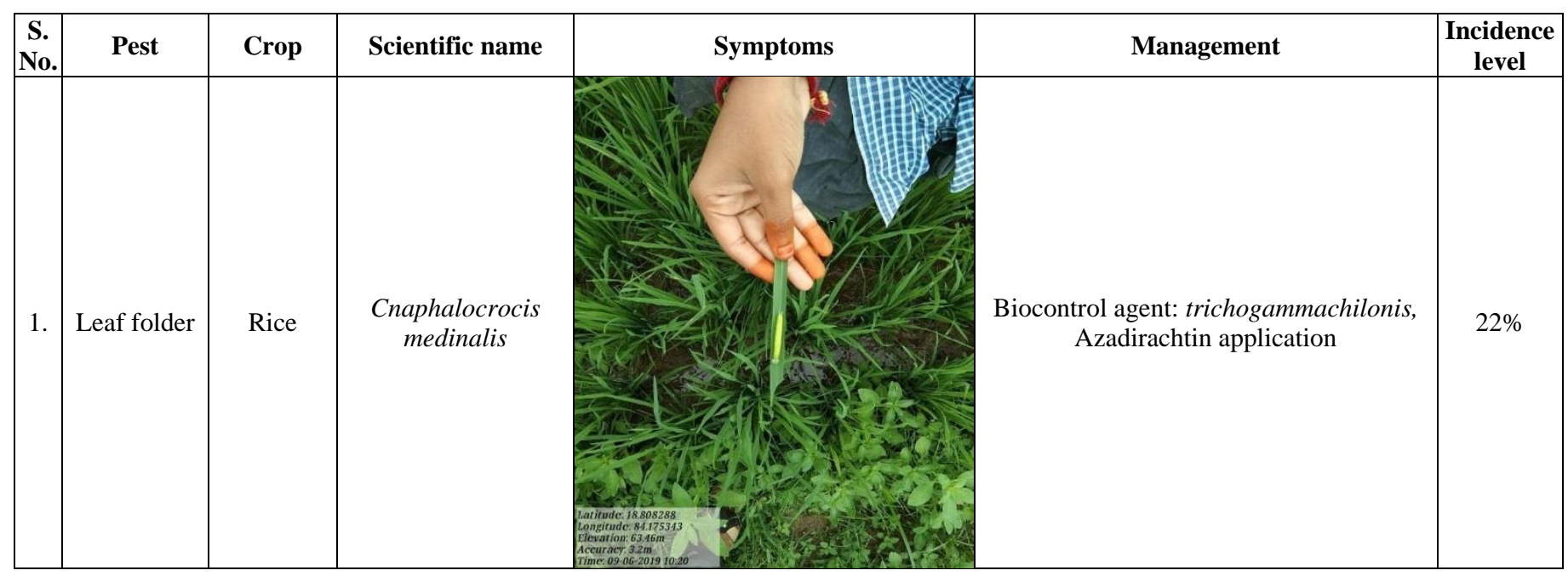




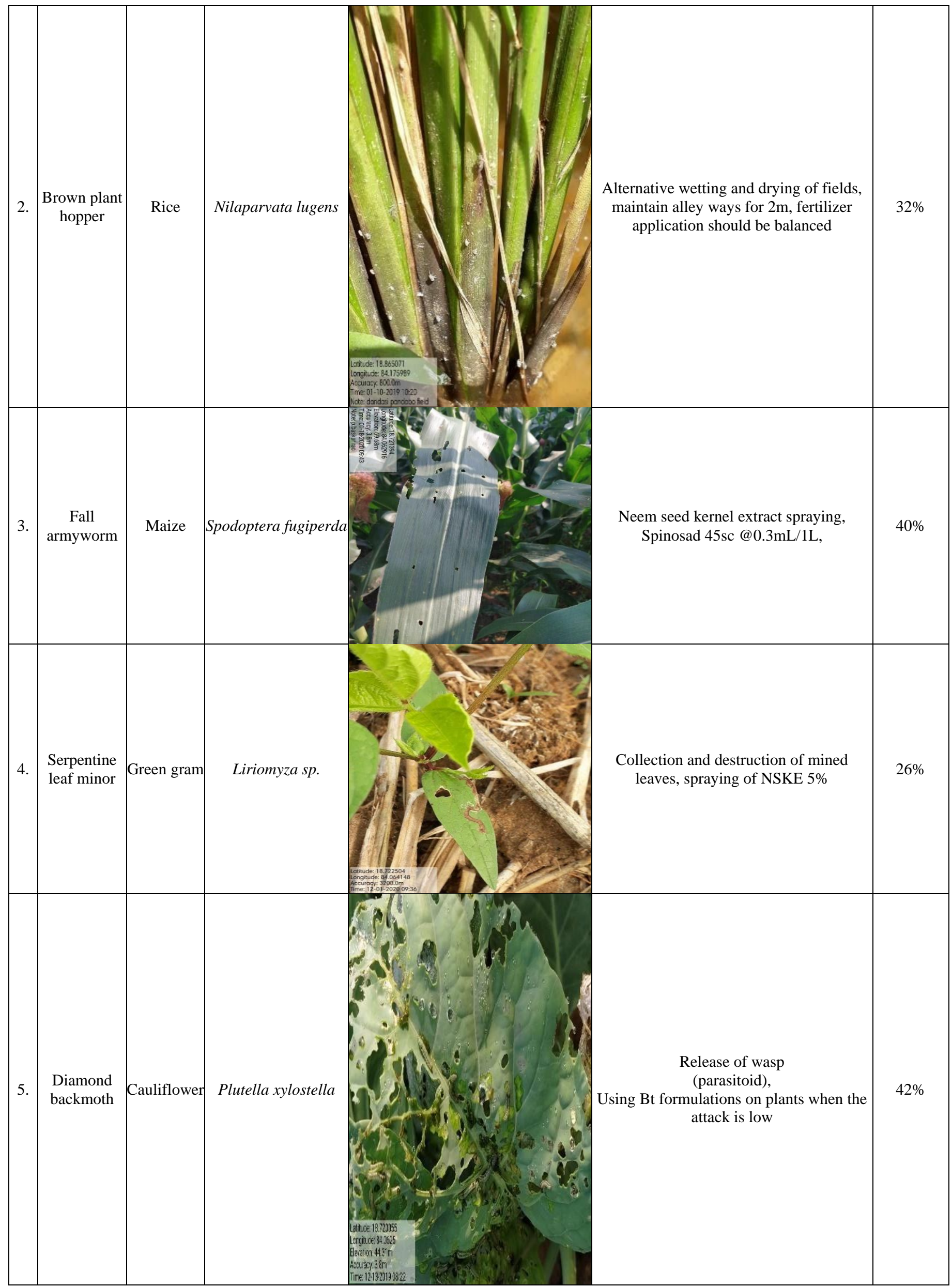




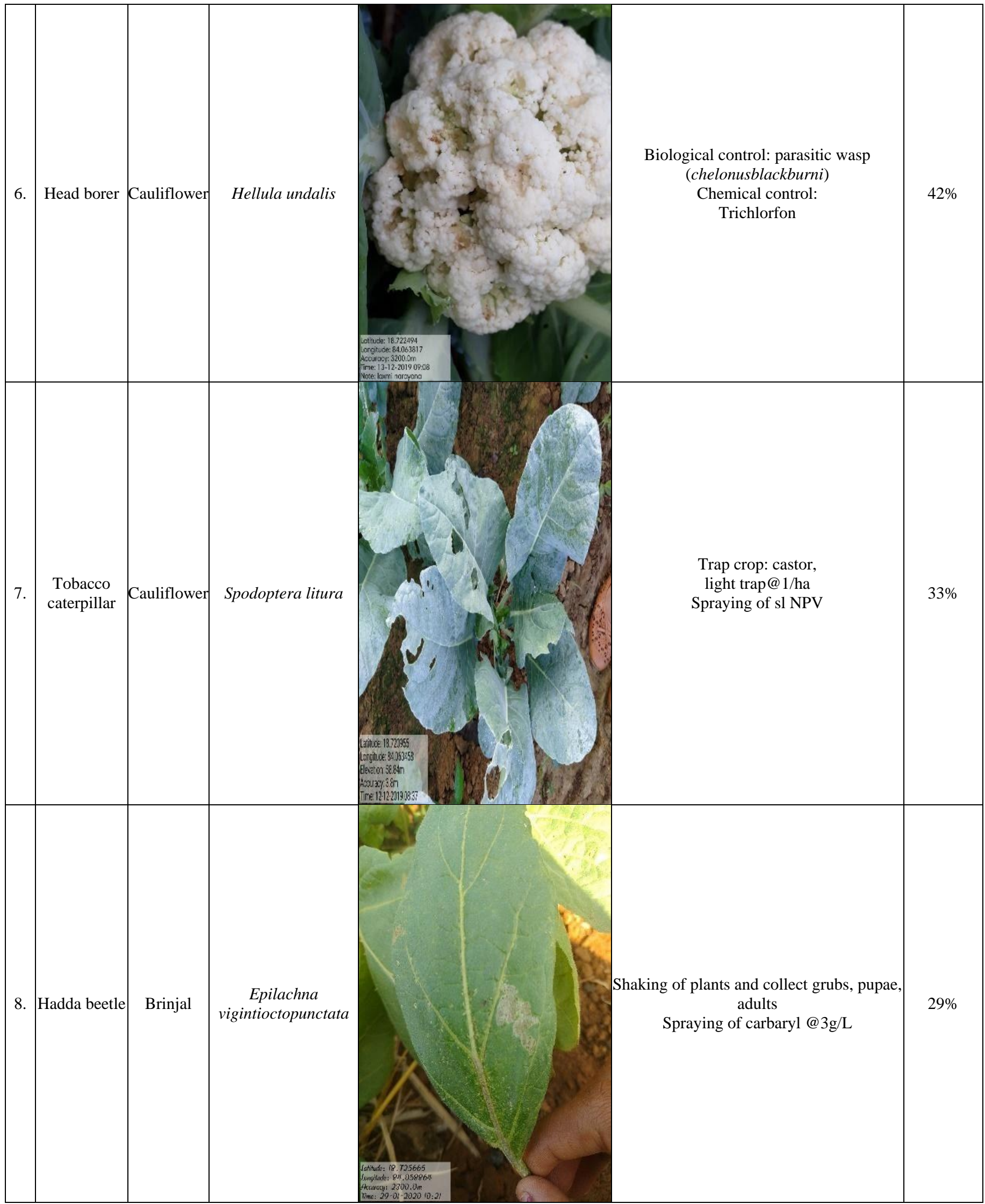

\section{Agro-economic loss data}

Agro-economic losses are due to biotic stresses were estimated under Table 3. The below given information is loss data of crops due to pests and diseases. Results revealed that in case of rice brown plant hopper infestation (30\%) is more followed by rice blast (28\%) and leaf folder (20\%). Similarly in case of maize fall armyworms $(40 \%)$, in case of cauliflower head borer $(45 \%)$ and in case of chilli disease incidence of anthracnose $(45 \%)$ is showed highest yield loss. Results were shown under the graphical representation of Figure 4. 
Table 3: Estimation of agro-economic loss, due to various biotic stresses

\begin{tabular}{|c|c|c|c|c|c|}
\hline S. No. & Crop & Potential yield/ha & Pest & Loss/ha & In Prcentage \\
\hline \multirow{3}{*}{1.} & \multirow{3}{*}{ Rice } & \multirow{3}{*}{5 ton } & Leaf folder & 1 ton & $20 \%$ \\
\hline & & & Brown plant hopper & 1.5 ton & $30 \%$ \\
\hline & & & Blast & 1.4 ton & $28 \%$ \\
\hline \multirow{2}{*}{2.} & \multirow{2}{*}{ Maize } & \multirow{2}{*}{ 7.5ton } & Fall armyworm & 3ton & $40 \%$ \\
\hline & & & Northern leaf blast & 1.1 ton & $15 \%$ \\
\hline \multirow{3}{*}{3.} & \multirow{3}{*}{ Cauliflower } & \multirow{3}{*}{25 tonn } & Head borer & 11ton & $45 \%$ \\
\hline & & & Tobacco caterpillar & 8.7 ton & $35 \%$ \\
\hline & & & Alternaria & 8ton & $32 \%$ \\
\hline \multirow{2}{*}{4.} & \multirow{2}{*}{ Chilli } & \multirow{2}{*}{10 tonn } & Fruit borer & 4 ton & $40 \%$ \\
\hline & & & Anthracnose & 4.5 ton & $45 \%$ \\
\hline
\end{tabular}

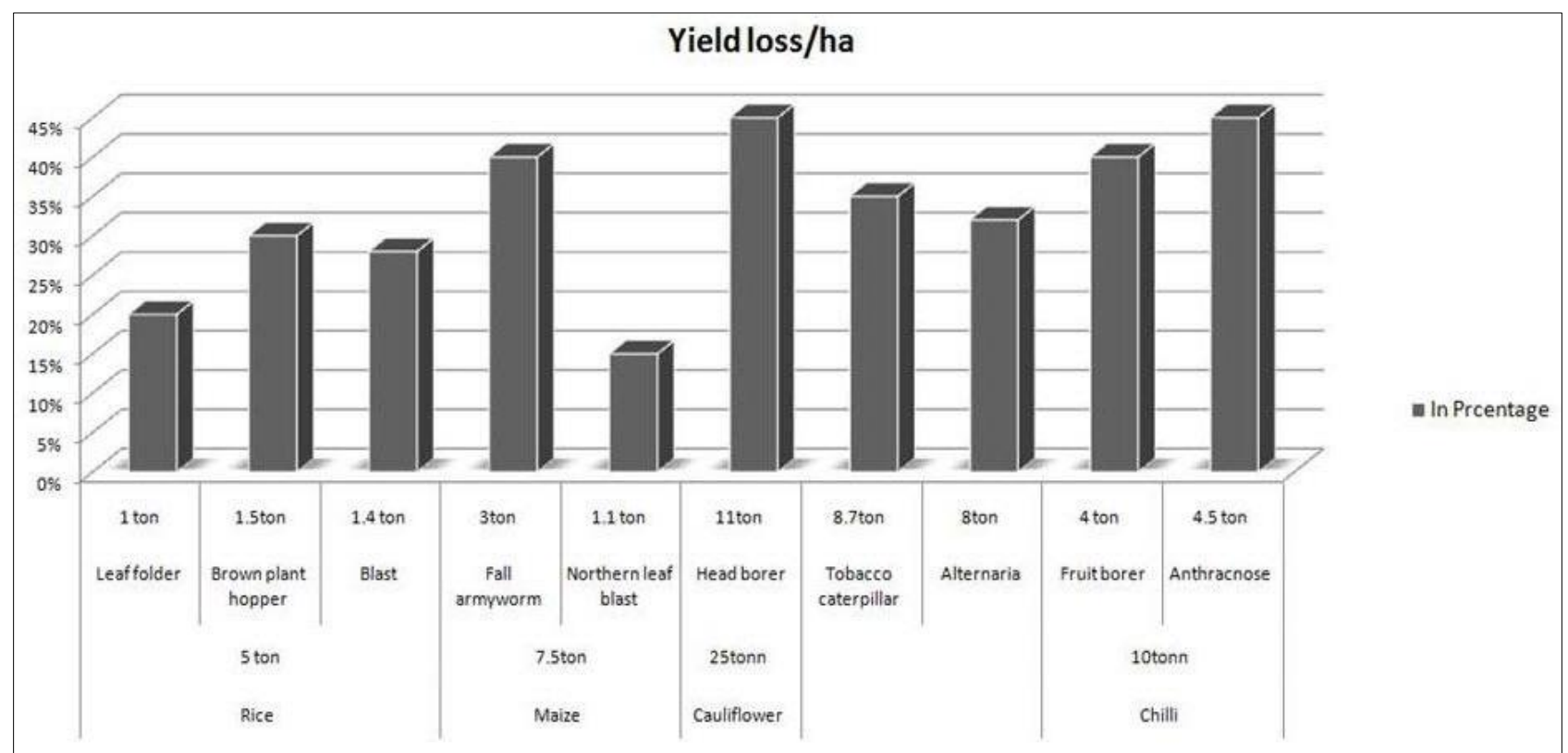

Fig 4: Graphical representation of yield loss of rice, maize, cauliflower and chilli due to major biotic stresses

\section{Comparison of chemicals and conventional methods} Various major biotic stresses were treated to control with both chemicals and conventional mixture components. Application of conventional mixture components is shown in Figure 5. Results revealed that conventional management strategies are more effective in terms of yield loss. Indefinite and unquantified doses of agrochemicals are causing severe phytotoxicity, which is another reason of yield loss. Comparative analysis of yield loss (chemicals and conventional methods) was represented through Table 4 and Figure 6.

Table 4: Comparative analysis of yield loss by using chemicals and conventional methods

\begin{tabular}{|c|c|c|c|c|c|c|}
\hline S. No. & Crop & Disease & Chemicals & Yield loss & Conventional methods & Yield loss \\
\hline 1. & Rice & Blast & SAAF & $28 \%$ & Beejamrutham & $20 \%$ \\
\hline 2. & Cauliflower & Alternaria leaf spot & Carbendazim & $35 \%$ & Beejamrutham & $21 \%$ \\
\hline 3. & Rice & Leaf roller & Acephate & $30 \%$ & Neemastram & $18 \%$ \\
\hline 4. & Cauliflower & Tobacco caterpillar & Triazophos & $35 \%$ & Neemastram & $15 \%$ \\
\hline 5. & Chilli & Fruit borer & Endosulfan & $33 \%$ & Agniastram & $10 \%$ \\
\hline 6. & Bhendi & White fly & Triazophos & $40 \%$ & Agniastram & $20 \%$ \\
\hline
\end{tabular}

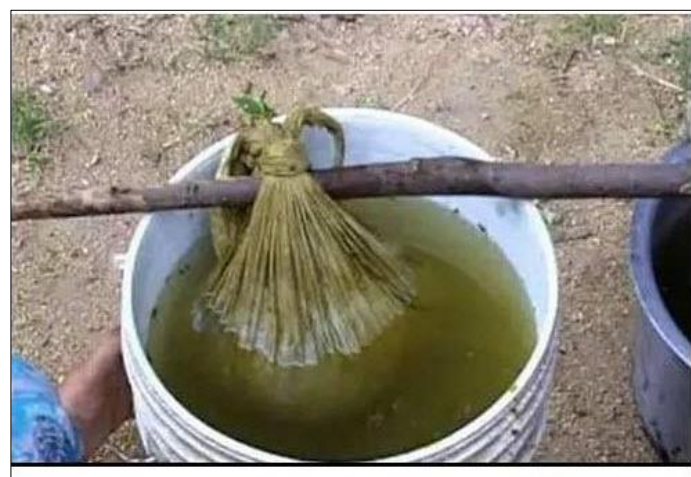

Preparation of Beejamrutham

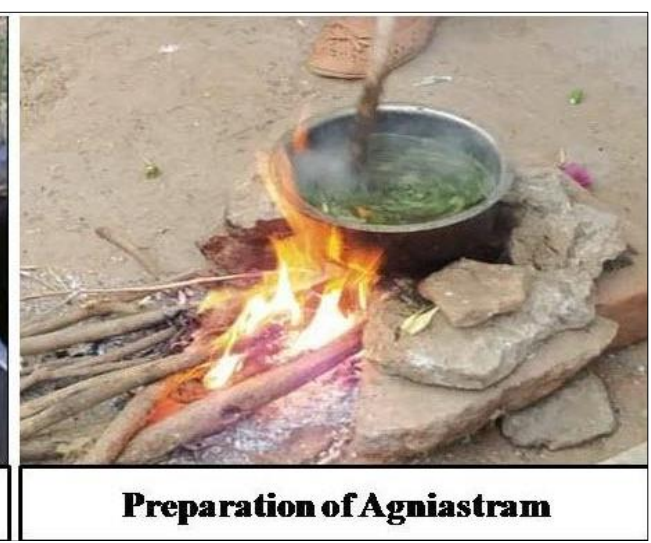




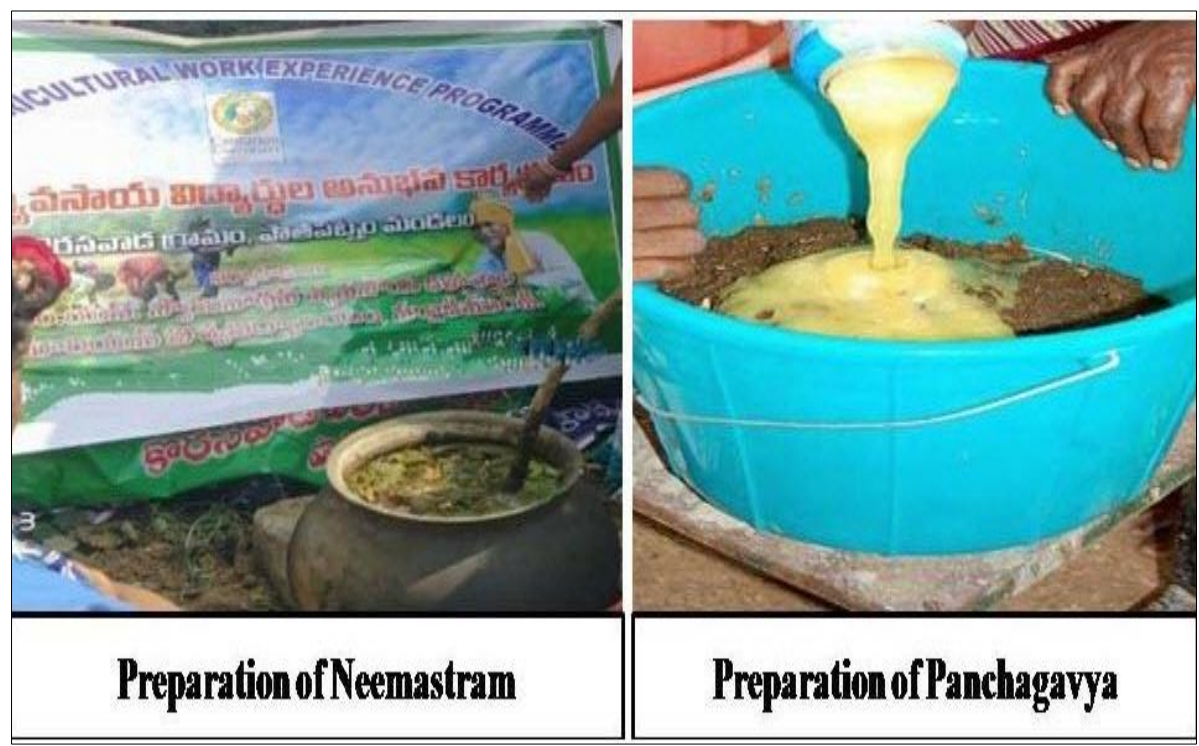

Fig 5: Application of conventional strategies for disease and pest management

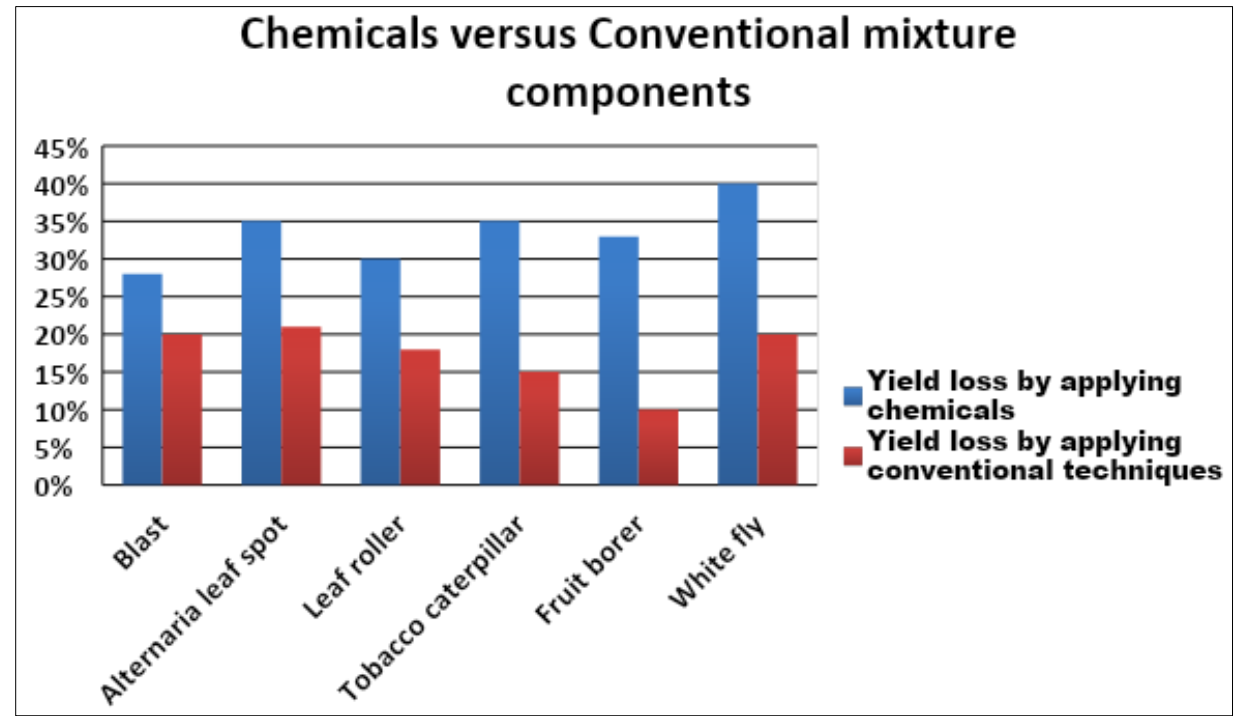

Fig 6: Graphical representation of controlling major biotic stresses through chemical management and conventional management strategies and their comparative analysis.

\section{Discussion}

Disease surveillance is a systematic approach or a practice to minimize the spread of a disease caused by outbreak, pandemic or epidemiological situations by keen monitoring, observation, to evaluate the disease patterns. For controlling of potential lethality of pest and pathogens continuous monitoring is needed. Disease surveillance is an only real tool for real-time response to outbreak of infectious disease. It can be performed in a limited resource setting which gives results accurately. After general surveillance, disease specific surveillance system is the best surveillance system for monitoring of epidemic, endemic or pandemic pathogen in the fields. Temperature, relative humidity, rainfall, sunshine, wind speed and many more epidemiological factors played a crucial role in disease establishment. Different epidemiological factors act as a catalyst in disease and pest infection cycle and wisely participated in disease introduction, establishment and spreading. Approximately $30-35^{\circ} \mathrm{C}$ temperature, $85-90 \%$ relative humidity and $120-150 \mathrm{~mm}$ average scattered rainfall makes a tri-directional pool in disease development and progress. Sometimes these epidemiological factors are considered for reemergence of any specific pathogen and nature of virulence is partially depending on it. Like as reemergence of Choanephora was reported by Das et al. in various crops like aubergine (2017) ${ }^{[5]}$, hyacinth bean $(2017)^{[3]}$, teasle gourd (2017) ${ }^{[2]}$, green pea (2017) ${ }^{[4]}$, papaya (2017) ${ }^{[8]}$, ban tulsi (2017) ${ }^{[6]}$, Amaranthus (2018) ${ }^{[7]}$ etc. Though, this pathogen was considered to be a minor pathogen at nineteenth century. Complex adoptability with preferential epidemiological factors makes the minor pathogen to a severe one. Pattanayak and Das (2020) ${ }^{[12]}$ reported severity of rice blast pathogen Magnaporthe grisea from the south eastern India which partially supports results of this investigation. Disease and pest modeling, disease prediction and forecasting are only possible through periodical and regular based surveillance data. Day by day increasing level chemical pesticides makes the situation more severe in terms of pathogen and pest resistant and soil health. Indigenous techniques or conventional strategies of disease and pest management, showing us alternate route map of sustainable agriculture. In this research paper we are trying to focus some conventional technique which used for long time and found to be effective in case of boosting the plant vigour as well as disease management. Association of diverse microbial colonies in 'Panchagavya' in the form of bioelicitor PGPR showed good plant health or growth enhancer. 
Environmental safety is a global concern, so it's our sole responsibility, to nurture with the component of this environment very carefully and conserve our extinct conventional farming technique for future generation.

\section{References}

1. Bishnoi R, Bhati A. An Overview: Zero budget natural farming. Trends in Bioscience. 2017; 10(46):9314-9316.

2. Das S, Dutta S, Chattopadhyay A, Mandal B. First report of Choanephora infundibulifera causing blossom blight of teasle gourd in India. Indian Phytopathology. 2017; 70(2):265-267.

3. Das S, Dutta S, Mandal B. First report of Choanephora cucurbitarum causing leaf blight of hyacinth bean in India. Journal of Plant Pathology. 2017; 99(2):533-543.

4. Das S, Dutta S, Kuiry SP, Mandal B. First report of twig blight disease of green pea (Pisum sativum) caused by Choanephora infundibulifera in India. Indian Phytopathology. 2017; 70(3):400-402.

5. Das S, Dutta S, Mandal B. First report on blossom and leaf blight of aubergine (Solanum melongena L.) caused by Choanephora infundibulifera (Currey) Sacc. in India. Journal of Mycology and Plant Pathology. 2017; 47(1):69-73.

6. Das S, Dutta S, Ray SK. First report of twig blight of ban tulsi (Croton bonplandianus) caused by Choanephora cucurbitarum in India. Journal of Plant Protection Research. 2017; 57(4):441-446.

7. Das S, Dutta S, Ray SK, Mondal B. First report of twig blight of lalshak (Amaranthus gangeticus L.) caused by Choanephora infundibulifera (Currey) Sacc. in India. Journal of Mycopathological Research 2018; 56(2):135139.

8. Das S, Dutta S, Roy-Barman A. First report of twig blight of papaya caused by Choanephora cucurbitarum in India. Indian Journal of Plant Protection. 2017; 45(4):393-395.

9. Fatma GR, Singh SN. Survey of root not disease of sponge gourd (Luffa cylindrica) at Muzaffarpur in city areas. Indian J Sci. Res. 2019; 10(2):27-32.

10. Ingole AR, Tapke RA. Bio enhancer using bio waste. International Journal of Current Advanced Research. 2017; 6(12):8362-8367.

11. Khadse A, Rosset PM, Morales H, Ferguson BG. Taking agroecology to scale: the zero budget natural farmingpeasant movement in Karnataka, India. The Journal of Peasant Studies. 2017; 45(1):192-219.

12. Pattanayak $S$, Das $S$. Outbreak of rice blast on the coastal region of south-eastern India. International Journal of Agriculture, Environment and Biotechnology. 2020; 13(1):59-70.

13. Plianbangchang $\mathrm{P}$, Jetiyanon $\mathrm{K}$, Wittaya-areekul $\mathrm{S}$. Pesticide use patterns among small-scale farmers: a case study from Phitsanulok, Thailand. Southeast Asian J Trop Med Public Health. 2009; 40(2):401-410.

14. Sailaja V, Ragini NN, Kumar KD, Reddy BR, Satyanarayana SV. Effect of foliar application of panchagavya on growth and development of leafy vegetable. International Journal of Agricultural and Food Science. 2014; 4(4):119-122.

15. Sharma PC, Kumar A, Mehta PK, Singh R. Survey studies on insects-pests associated with important medicinal plants in Himachal Pradesh. Ind. J Sci. Res and Tech. 2014; 2(4):2-7. 